\title{
IgG4-related Disease with a Cardiac Mass
}

\author{
Ikuko Matsumura ${ }^{1}$, Takeki Mitsui ${ }^{1}$, Kenichi Tahara ${ }^{1}$, Hiroaki Shimizu ${ }^{1}, K_{\text {Knio Yanagisawa }}{ }^{2}$, \\ Takuma Ishizaki ${ }^{1}$, Hiromi Koiso ${ }^{2}$, Makiko Takizawa ${ }^{1}$, Akihiko Yokohama ${ }^{3}$, Takayuki Saitoh ${ }^{4}$, \\ Junko Hirato ${ }^{5}$, Hirokazu Murakami ${ }^{4}$, Hiroshi Handa ${ }^{1}$ and Norifumi Tsukamoto ${ }^{6}$
}

\begin{abstract}
:
A 69-year-old man with palpitations and decreased blood pressure was referred. Echocardiography showed a mass in the right atrium and cardiac septum. The serum IgG4 level was 1,450 mg/dL. A biopsy of the cardiac mass showed fibrosis with inflammatory cells and increased IgG4-positive plasma cells and lymphocytes. Flow cytometry and polymerase chain reaction of the immunoglobulin heavy chain did not demonstrate monoclonality. He was diagnosed with IgG4-related disease (IgG4-RD). IgG4-RD with a cardiac mass is rare and it is difficult to distinguish it from malignant lymphoma by a pathological examination alone. We therefore performed a biopsy and analyzed the clonality in order to make an accurate diagnosis of IgG4-RD.
\end{abstract}

Key words: IgG4-related disease, non-Hodgkin lymphoma, cardiac mass

(Intern Med 59: 1203-1209, 2020)

(DOI: 10.2169/internalmedicine.4054-19)

\section{Introduction}

IgG4-related disease (IgG4-RD) is a systemic fibroinflammatory disease characterized by elevated serum IgG4 levels, increased IgG4-positive plasma cells and lymphocytes, and the tumor-like involvement of one or more exocrine glands or other extranodal sites with lymphoplasmacytic infiltrates and sclerosis (1). The major involved organs are the salivary glands, lacrimal glands, pancreas, and retroperitoneal space (1-5). IgG4-RD characteristically responds to glucocorticoid therapy (1).

Cardiac masses include hematoma, tumors, vegetations, calcific lesions, and other rare conditions. Cardiac tumors are rare and include a variety of benign and malignant entities. Reynen et al. reported that the frequency of primary cardiac tumors was $0.02 \%$ based on the data of 22 autopsy series (6). The most common tumors that involve the heart are metastatic neoplasms. The incidence of metastatic tumors of the heart was $1.23 \%$ in an autopsy series. The most common metastatic tumors of the heart are from lung carci- noma (7). Myxomas represent the most common benign tumor, whereas sarcomas account for most primary malignant neoplasms of the cardiac muscles (8). IgG4-RD of the heart, especially involving the cardiac muscles, is very rare. To our knowledge, there have been 13 reports of IgG4-RD affecting the heart (9-20), with 4 of those 13 reports on $\operatorname{IgG} 4-\mathrm{RD}$ of the atrium, ventricle, and ventricular septum $(12,13,19,20)$.

The diagnosis of IgG4-RD is based on the histopathologic features, disease site, and serum IgG4 levels. Malignant lymphoma is a histopathologic mimicker of IgG4-RD. Therefore, it is difficult to discriminate IgG4-RD involving a rare site from malignant lymphoma in daily practice. We herein report the case of a patient with $\operatorname{IgG} 4-\mathrm{RD}$ with a mass lesion in the right atrium that was difficult to discriminate from malignant lymphoma.

\section{Case Report}

A 69-year-old Japanese man was referred to our hospital because of vertigo, palpitations, and decreased blood pres-

\footnotetext{
${ }^{1}$ Department of Hematology, Gunma University Graduate School of Medicine, Japan, ${ }^{2}$ Infection Control and Prevention Center, Gunma University Hospital, Japan, ${ }^{3}$ Division of Blood Transfusion Service, Gunma University Hospital, Japan, ${ }^{4}$ Department of Laboratory Sciences, Gunma University Graduate School of Health Science, Japan, ${ }^{5}$ Department of Pathology, Gunma University Hospital, Japan and ${ }^{6}$ Oncology Center, Gunma University Hospital, Japan

Received: October 13, 2019; Accepted: November 25, 2019; Advance Publication by J-STAGE: January 17, 2020

Correspondence to Dr. Norifumi Tsukamoto, tsukamoto@gunma-u.ac.jp
} 
Table 1. Laboratory Findings on Admission.

\begin{tabular}{cclclr}
\hline \multicolumn{5}{c}{ Blood Cell Count } & \multicolumn{1}{c}{ Biochemical test } \\
\hline WBC & $5,300 / \mu \mathrm{L}$ & $\mathrm{TP}$ & $8.9 \mathrm{~g} / \mathrm{dL}$ & $\mathrm{BNP}$ & $97.6 \mathrm{pg} / \mathrm{mL}$ \\
$\mathrm{Neu}$ & $32.9 \%$ & $\mathrm{Alb}$ & $2.9 \mathrm{~g} / \mathrm{dL}$ & $\mathrm{IgG}$ & $5,294 \mathrm{mg} / \mathrm{dL}$ \\
$\mathrm{Eos}$ & $28.3 \%$ & $\mathrm{~T}-\mathrm{Bil}$ & $0.3 \mathrm{mg} / \mathrm{dL}$ & $\mathrm{IgA}$ & $67 \mathrm{mg} / \mathrm{dL}$ \\
$\mathrm{Ba}$ & $2.8 \%$ & $\mathrm{AST}$ & $34 \mathrm{U} / \mathrm{L}$ & $\mathrm{IgM}$ & $43 \mathrm{mg} / \mathrm{dL}$ \\
$\mathrm{Mo}$ & $7.0 \%$ & $\mathrm{ALT}$ & $41 \mathrm{U} / \mathrm{L}$ & $\mathrm{IgG} 4$ & $1,450 \mathrm{mg} / \mathrm{dL}$ \\
$\mathrm{Ly}$ & $29.0 \%$ & $\mathrm{LDH}$ & $151 \mathrm{U} / \mathrm{L}$ & $\mathrm{sIL}-2 \mathrm{R}$ & $1,672 \mathrm{U} / \mathrm{mL}$ \\
$\mathrm{RBC}$ & $3.5310^{6} / \mu \mathrm{L}$ & $\mathrm{Cr}$ & $0.78 \mathrm{mg} / \mathrm{dL}$ & $\beta 2 \mathrm{MG}$ & $4.2 \mathrm{mg} / \mathrm{L}$ \\
$\mathrm{MCV}$ & $86.7 \mathrm{fl}$ & $\mathrm{Na}$ & $135 \mathrm{mEq} / \mathrm{L}$ & Coagulation test \\
$\mathrm{MCH}$ & $28.6 \mathrm{pg}$ & $\mathrm{K}$ & $4.3 \mathrm{mEq} / \mathrm{L}$ & $\mathrm{PT}$ & $74 \%$ \\
$\mathrm{MCHC}$ & $33.0 \mathrm{~g} / \mathrm{dL}$ & $\mathrm{Cl}$ & $101 \mathrm{mEq} / \mathrm{L}$ & $\mathrm{APTT}$ & $32.3 \mathrm{sec}$ \\
$\mathrm{Hb}$ & $10.1 \mathrm{~g} / \mathrm{dL}$ & $\mathrm{Ca}$ & $8.6 \mathrm{mg} / \mathrm{dL}$ & Fib & $312 \mathrm{mg} / \mathrm{dL}$ \\
$\mathrm{Plt}$ & $26410^{3} / \mu \mathrm{L}$ & $\mathrm{CRP}$ & $0.27 \mathrm{mg} / \mathrm{dL}$ & FDP & $8.4 \mu \mathrm{g} / \mathrm{dL}$ \\
\hline
\end{tabular}

sure. His medical history included appendicitis, cholecystitis, lumbar discitis, iliopsoas abscess, and spinal canal stenosis. A physical examination on admission showed swelling of the maxilla, bilateral lacrimal glands, and subcutaneous nodules of bilateral upper arms, but tachycardia and decreased blood pressure were not observed after the administration of verapamil hydrochloride.

Laboratory data are shown in Table 1. Blood cell counts and the liver and renal function were normal. Serum lactate dehydrogenase $(\mathrm{LDH})$ was not elevated. The total protein level was $8.9 \mathrm{~g} / \mathrm{dL}$ (normal range, 6.3-7.9), and the serum albumin level was $2.9 \mathrm{~g} / \mathrm{dL}$ (normal range, 3.9-5.0). Serum IgG and IgG4 levels were 5,294 mg/dL (normal range, 8701,700 ) and 1,450 mg/dL (normal range, 4-108), respectively, whereas other immunoglobulin levels were in the normal ranges. However, serum IgG- $\kappa$ type M-protein was detected by an immunofixation test. Soluble interleukin-2 receptor (sIL-2R) was 1,672 U/mL (normal range, 246-742). The serum brain natriuretic peptide (BNP) level was $97.6 \mathrm{pg} / \mathrm{mL}$ (normal range, 0-18.4).

Echocardiography and computed tomography (CT) showed a right atrial tumor that infiltrated into the cardiac septum (Fig. 1A, B). ${ }^{18}$ F-fluorodeoxyglucose positron emission tomography/CT $\left({ }^{18} \mathrm{~F}\right.$-FDG-PET/CT), which was performed after a cardiac mass biopsy, showed the accumulation of ${ }^{18} \mathrm{~F}$-FDG in the cardiac muscle [maximum standardize uptake value $\left.\left(\mathrm{SUV}_{\max }\right), 5.2\right]$, mediastinal lymph nodes, lacrimal glands, salivary glands, and subcutaneous nodules in the bilateral upper arms (Fig. 1C). The electrocardiogram showed first-degree atrioventricular block (Fig. 1D).

Because of his symptoms of cardiac mass, tachycardia, and decreased blood pressure, cardiac mass reduction was urgently required. Therefore, the patient underwent a cardiac tumor biopsy. Flow cytometry showed a normal kappa/ lambda ratio in the lymphocyte population (Fig. 2A). On low-magnification light microscopy, follicles of various sizes were found to be distributed irregularly in the tumor (Fig. 2B). Slightly atrophic germinal centers containing fibrosis and infiltrating small vessels were observed. At high magnification, a polymorphous population consisting of nu- merous mature plasma cells, plasmacytoid cells, and smallto medium-sized lymphocytes was found to have infiltrated diffusely (Fig. 2C). Staining with CD3 and CD20 showed a mixture of small and medium-sized lymphocytes and immunoblasts (Fig. 2D, E). Immunohistochemical studies of light chain determinants for interfollicular plasma cells, plasmacytoid cells, and B-immunoblasts demonstrated a polyclonal pattern (Fig. 2F, G). There were many IgG-positive cells in the lesion (Fig. 2H), with IgG4-positive cells accounting for over 50\% of IgG-positive plasma cells (Fig. 2I).

IgG4-RD and malignant lymphoma are very rare in the cardiac muscle. The differential diagnosis between IgG4-RD and malignant lymphoma can be difficult when involving a rare disease site. Furthermore, IgG- $\kappa \mathrm{M}$-protein was detected in this patient. We need to distinguish between IgG4-RD and malignant lymphoma carefully. Therefore, to examine the clonality of the cardiac biopsy specimen, polymerase chain reaction (PCR) of the immunoglobulin heavy chain $(\mathrm{IgH})$ genes was performed using DNA extracted from fresh-frozen biopsy specimen as templates. A total of $100 \mathrm{ng}$ of DNA was amplified by PCR (21). When the products were electrophoresed on a $4-20 \%$ gradient polyacrylamide gel (TEFCO, Tokyo, Japan), a single band representing the clonal cell expansion of B cells was not detected in the cardiac biopsy specimen (22) (Fig. 3). Based on these pathological findings and the results of the clonal analysis of the IgH gene, IgG4-RD was diagnosed.

The patient's clinical course is shown in Fig. 4. With the daily administration of $30 \mathrm{mg}$ prednisolone $(0.6 \mathrm{mg} / \mathrm{kg} /$ day $)$, the cardiac mass and subcutaneous nodule shrank, and the serum IgG4 level decreased. After 4 weeks' administration of $30 \mathrm{mg}$ prednisolone daily, the dosage of prednisolone was tapered to a maintenance dose. After one-year administration of prednisolone, CT and echocardiography showed that the cardiac mass had shrunk even further but was still present (Fig. 5). The patient's clinical course was uneventful for 12 months. 
A

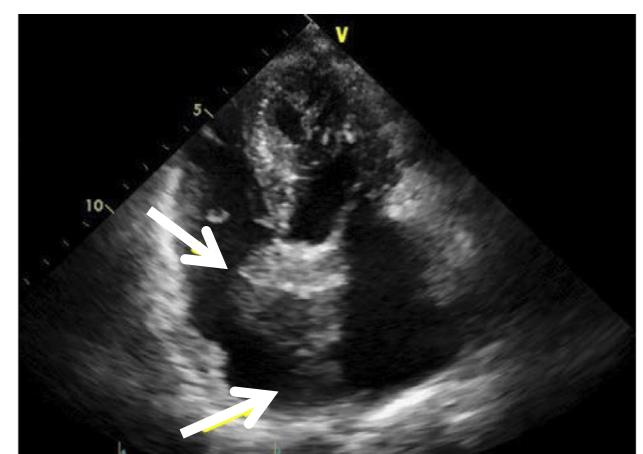

B

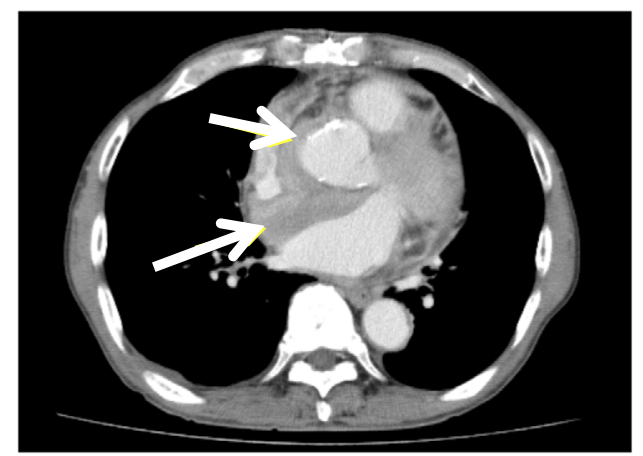

C

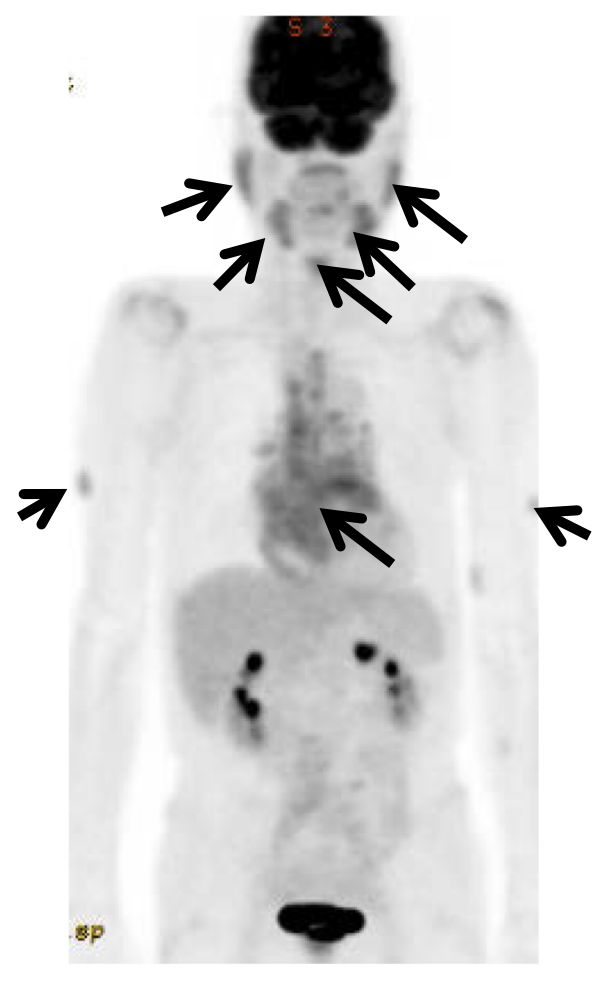

D

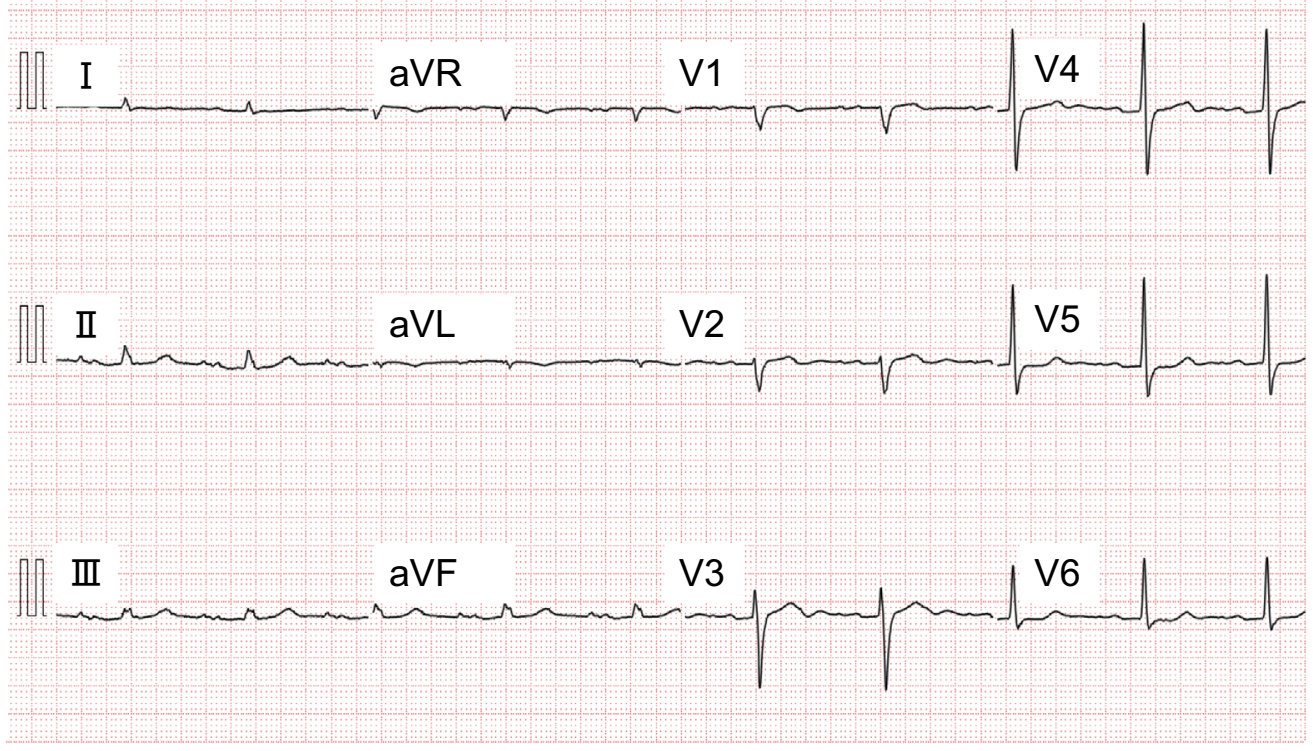

Figure 1. (A, B) Echocardiography and CT showing a right atrial tumor infiltrating the cardiac septum at the diagnosis (white arrow). (C) ${ }^{18}$ F-FDG-PET/CT showing the accumulation of ${ }^{18}$ F-FDG in the cardiac muscle, mediastinal lymph nodes, lacrimal glands, salivary glands, and subcutaneous nodules in the bilateral upper arms at the diagnosis (block arrow). (D) An electrocardiogram showing first-degree atrioventricular block.

\section{Discussion}

IgG4-RD frequently involves the salivary glands, lacrimal glands, pancreas, lymph nodes, and retroperitoneal space (1-5). IgG4-RD involving the heart is very rare. Among the cases of IgG4-RD involving the heart (Table 2), the median age was 59.5 (range: 52-75) years, and the most 

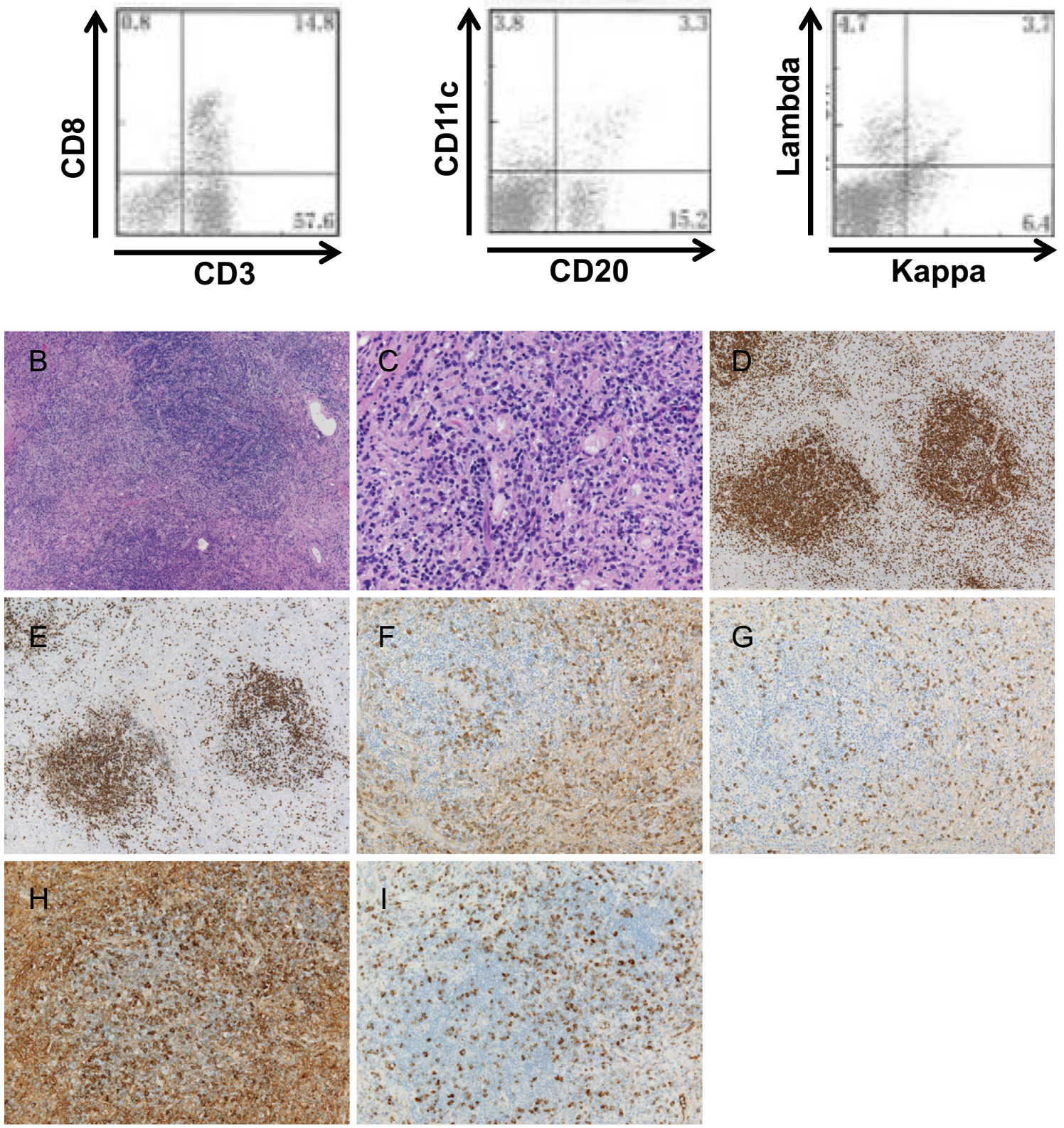

Figure 2. Histological findings of the cardiac mass. (A) Flow cytometry shows that the kappa/lambda ratio is in the normal range. (B) Hematoxylin and Eosin $(H \& E)$ staining $(\times 40)$. Various sizes of follicles are distributed irregularly in the tumor. Slightly atrophic germinal centers containing fibrosis and infiltration of small vessels are observed. (C) H\&E staining $(\times 200)$. Proliferation of immunoblast-like cells and heavy infiltration of mature plasma cells and small lymphocytes are observed in the interfollicular area. (D, E) Staining with CD3 (D) and CD20 (E) shows a mixture of small and medium-sized lymphocytes and immunoblasts. (F, G) Immunohistochemical studies of light chain, kappa (F) and lambda (G), determinants for interfollicular plasma cells, plasma cytoid cells, and Bimmunoblasts demonstrate a polyclonal pattern $(\times 100)$. (H) There are numerous IgG-positive cells in the lesion $(\times 100)$. (I) Over 50\% of the IgG-positive cells are IgG4-positive $(\times 100)$.

commonly affected regions were the coronary arteries and aortic and mitral valves. The most common first symptoms were syncope, dyspnea, and chest pain. However, sudden cardiac death occurred in some patients with coronary artery lesions. Regarding the treatment of IgG4-RD of the heart, nine cases have been reportedly treated via surgery, such as tumor resection and/or replacement of a cardiac valve (9, $10,13,15,17-20)$. Two cases required pacemaker implantation $(12,13)$, and one case received rituximab treatment (18). The first-line, standard-of care approach for most IgG4-RD patients is glucocorticoid administration. While previous reports showed that only three patients were treated 


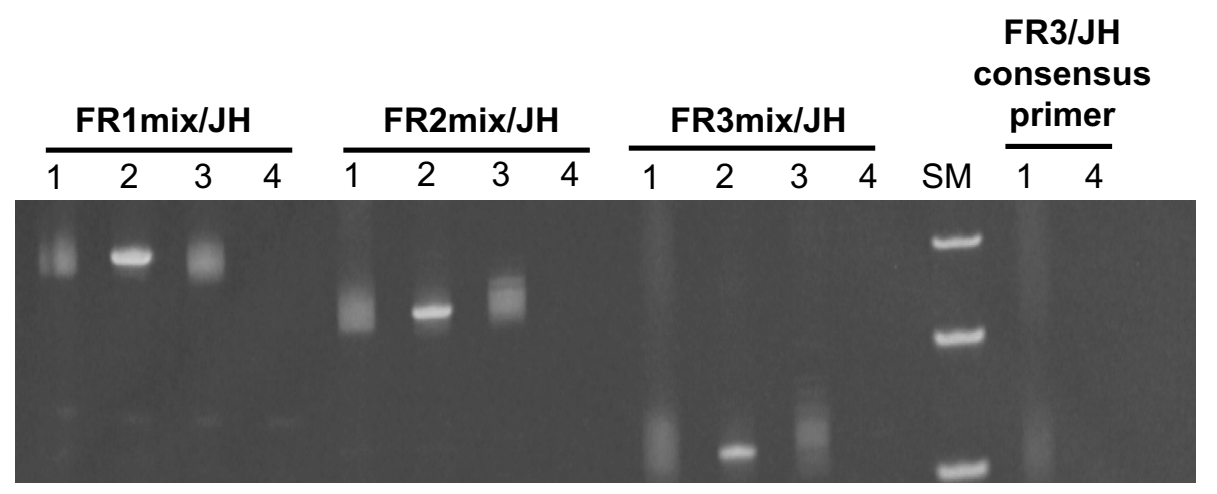

Figure 3. PCR for IgH rearrangement in the cardiac biopsy specimen at the diagnosis. The lanes are: 1, patient; 2 , clonal control; 3, polyclonal control; and 4, $\mathrm{H}_{2} \mathrm{O}$, SM: size marker

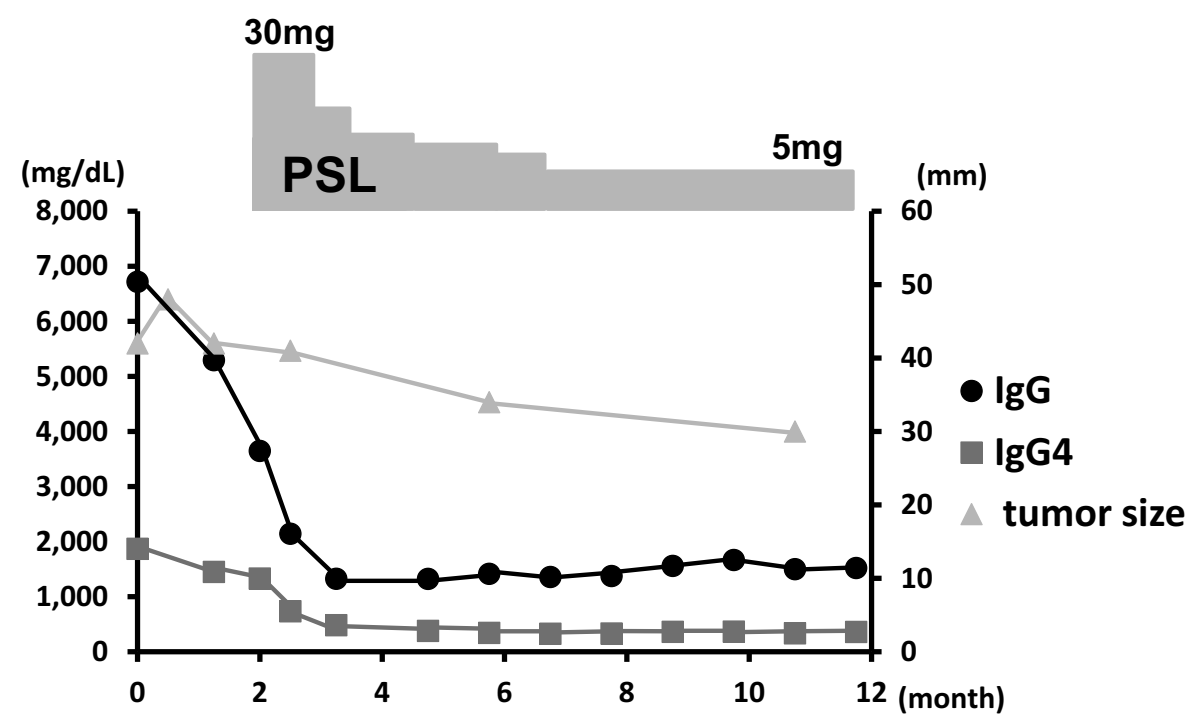

Figure 4. Clinical course of this patient.
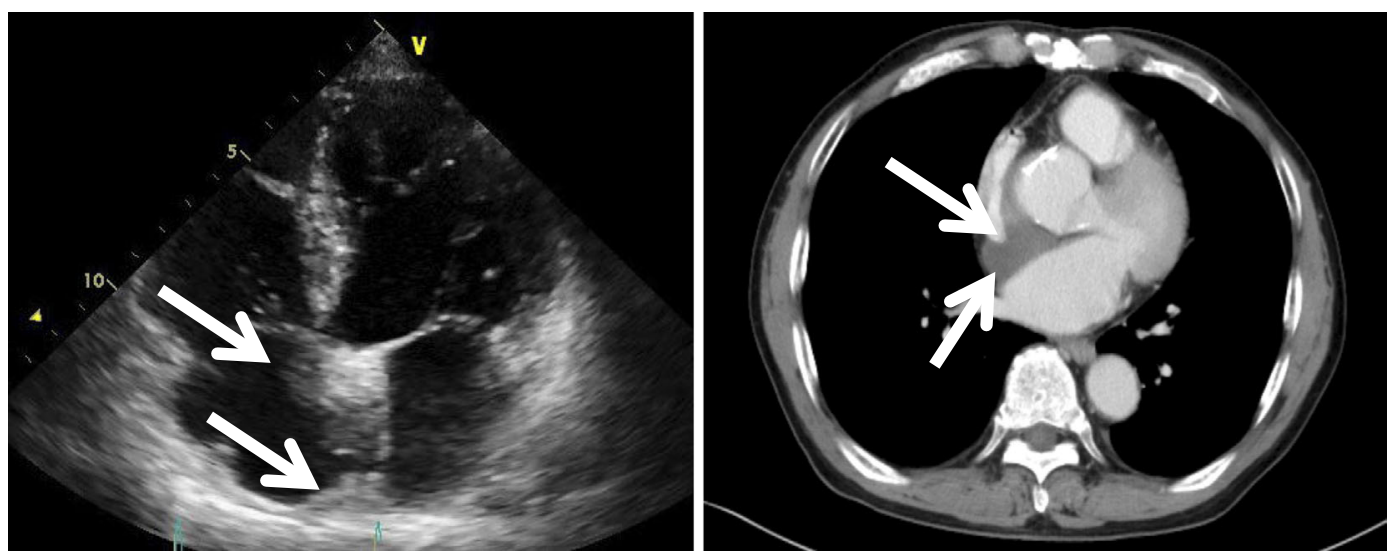

Figure 5. Echocardiography and CT showing shrinkage of the cardiac mass after one year.

with glucocorticoids, all three showed an uneventful course after the administration of glucocorticoids $(10,19,20)$. In the present patient, only prednisolone was administered because of the multifocal lesions. The mass lesions shrank gradually, and the serum IgG4 level decreased (Fig. 4).

Cardiac IgG4-RD is very rare, so it is clinically important to discriminate between IgG4-RD and malignant lymphoma, which is a histopathologic mimicker of IgG4. There have been several reports of the development of non-Hodgkin's lymphoma (NHL) superimposed on IgG4-RD (23-25). Among the cases of IgG4-RD with malignant lymphoma, especially that involving the ocular adnexa and salivary 
Table 2. Cases of IgG4-related Disease with a Cardiac Mass.

\begin{tabular}{|c|c|c|c|c|c|c|c|}
\hline Case & Age (y) & Sex & Symptom & & Site of disease & Treatment & Clinical course \\
\hline 1 & 63 & $\mathrm{~F}$ & $\begin{array}{l}\text { Abdominal mass, SOB } \\
\text { Palpitation }\end{array}$ & $\mathrm{CA}$ & AAA & Operation & Uneventful for $5 \mathrm{mo}$ \\
\hline 2 & 75 & $\mathrm{M}$ & Chest Pain & $\mathrm{CA}$ & $\begin{array}{l}\text { Pancreas, Parotid } \\
\text { glands }\end{array}$ & $\begin{array}{l}\text { Operation, } \\
\text { Steroid }\end{array}$ & Angina-free for $4 \mathrm{mo}$ \\
\hline 3 & 61 & M & & $\mathrm{CA}$ & & & Sudden death \\
\hline 4 & 55 & $\mathrm{~F}$ & Syncope, Dizziness & RA, AS & & Pacemaker & Uneventful for $12 \mathrm{mo}$ \\
\hline 5 & 59 & $\mathrm{~F}$ & SOB, Leg edema & LA & & $\begin{array}{l}\text { Operation, } \\
\text { Pacemaker }\end{array}$ & Uneventful for $6 \mathrm{mo}$ \\
\hline 6 & 54 & $\mathrm{M}$ & Syncope & $\mathrm{CA}$ & & & Sudden death \\
\hline 7 & 58 & $\mathrm{~F}$ & Syncope & PV & & Operation & Uneventful for $16 \mathrm{mo}$ \\
\hline 8 & 53 & M & Chest pain & $\mathrm{CA}$ & Kidney, Pancreas, LN & & Sudden death \\
\hline 9 & 64 & $\mathrm{~F}$ & SOB & $\mathrm{MV}, \mathrm{AV}$ & & Operation & Uneventful for $6 \mathrm{mo}$ \\
\hline 10 & 60 & $\mathrm{~F}$ & $\begin{array}{c}\text { Chest oppression, SOB } \\
\text { General malaise }\end{array}$ & AV & & Operation & Valve function improved \\
\hline 11 & 70 & $\mathrm{M}$ & SOB, Dizziness & $\mathrm{AV}$ & Pancreas & $\begin{array}{l}\text { Operation, } \\
\text { Rituximab }\end{array}$ & $\begin{array}{l}\text { Bioprosthesis function was } \\
\text { well after } 5 \text { mo }\end{array}$ \\
\hline 12 & 52 & $\mathrm{M}$ & Chest pain & $\mathrm{RV}$ & TAA & $\begin{array}{l}\text { Operation, } \\
\text { Steroid }\end{array}$ & No recurrence \\
\hline 13 & 64 & $\mathrm{M}$ & & PV, RV & & $\begin{array}{l}\text { Operation, } \\
\text { Steroid }\end{array}$ & No recurrence for $48 \mathrm{mo}$ \\
\hline $\begin{array}{c}14 \\
\text { Present } \\
\text { case }\end{array}$ & 69 & $\mathrm{M}$ & $\begin{array}{l}\text { Tachycardia, } \\
\text { Hypotension }\end{array}$ & RA, AS & $\begin{array}{l}\text { Lacrimal, Salivary, } \\
\text { Submandibular glands, } \\
\text { Subcutaneous }\end{array}$ & Steroid & Tumor shrank after $12 \mathrm{mo}$ \\
\hline
\end{tabular}

F: female, M: male, SOB: shortness of breath, CA: coronary artery, RA: right atrium, AS: atrial septum, LA: left atrium, PV: pulmonary valve, MV: mitral valve, AV: aortic valve, RV: right ventricle, AAA: abdominal aortic aneurysm, LN: lymph node, TAA: thoracic aortic aneurysm, mo: months

glands, most showed mucosa associated lymphoid tissue (MALT) lymphoma $(23,26)$, and some $\operatorname{IgG} 4$-producing cells were identified as neoplastic (24). There have been several reports of IgG4-RD following malignant lymphoma (27-29). Therefore, it is difficult to discriminate $\mathrm{IgG}$ 4-RD at a rare site from malignant lymphoma in daily practice.

To avoid inappropriate treatment in patients suspected of having malignant lymphoma, clarifying the clonality of the specimen is important. Several methods for examining the clonality have been reported, including flow cytometry, Southern blotting, and PCR of the $\operatorname{IgH}$ gene. For PCR of the $\operatorname{IgH}$ gene, DNA from not only fresh-frozen specimens but also formalin-fixed paraffin-embedded tissue samples can be used. In the present case, the clonality of the $\operatorname{IgH}$ gene was analyzed by PCR using fresh-frozen specimens, and no clonality was found. Based on the pathological findings and the PCR results, this patient was diagnosed with IgG4-RD. The patient was then treated with prednisolone, and inappropriate chemotherapy was avoided. However, we need to continue following this patient carefully for a long period because M-protein was detected.

In conclusion, this rare case of IgG4-RD with a cardiac mass was difficult to distinguish from malignant lymphoma by a pathological examination alone. We therefore performed a biopsy to analyze the clonality of the cardiac tumor and made an accurate diagnosis of IgG4-RD.

The authors state that they have no Conflict of Interest (COI).

\section{Financial Support}

This study was supported in part by a Grant-in-Aid for Scientific Research (C), and by the National Cancer Research and Development Fund (29-A-3).

\section{References}

1. Masaki Y, Kurose N, Umehara H. IgG4-related disease: a novel lymphoproliferative disorder discovered and established in Japan in the 21st century. J Clin Exp Hematop 51: 13-20, 2011.

2. Hamano H, Kawa S, Horiuchi A, et al. High serum IgG4 concentrations in patients with sclerosing pancreatitis. N Engl J Med 344: 732-738, 2001.

3. Cheuk W, Yuen HK, Chan JK. Chronic sclerosing dacryoadenitis: part of the spectrum of IgG4-related Sclerosing disease? Am J Surg Pathol 31: 643-645, 2007.

4. Hamano H, Arakura N, Muraki T, Ozaki Y, Kiyosawa K, Kawa S. Prevalence and distribution of extrapancreatic lesions complicating autoimmune pancreatitis. J Gastroenterol 41: 1197-1205, 2006.

5. Kitagawa S, Zen Y, Harada K, et al. Abundant IgG4-positive plasma cell infiltration characterizes chronic sclerosing sialadenitis (Kuttner's tumor). Am J Surg Pathol 29: 783-791, 2005.

6. Reynen K. Frequency of primary tumors of the heart. Am J Cardiol 77: 107, 1996.

7. Lam KY, Dickens P, Chan AC. Tumors of the heart. A 20-year experience with a review of 12,485 consecutive autopsies. Arch Pathol Lab Med 117: 1027-1031, 1993.

8. Burke A, Virmani R. Atlas of tumor pathology. In: Tumors of the Heart and Great Vessels. 3rd series, fascicle 16. Armed Forces Institute of Pathology, Washington, DC, 1996: 127-170.

9. Matsumoto Y, Kasashima S, Kawashima A, et al. A case of multiple immunoglobulin G4-related periarteritis: a tumorous lesion of the coronary artery and abdominal aortic aneurysm. Hum Pathol 39: 975-980, 2008. 
10. Ikutomi M, Matsumura $T$, Iwata $H$, et al. Giant tumorous lesions (correction of legions) surrounding the right coronary artery associated with immunoglobulin-G4-related systemic disease. Cardiology 120: 22-26, 2011.

11. Holmes BJ, Delev NG, Pasternack GR, Halushka MK. Novel cause of sudden cardiac death: IgG4-related disease. Circulation 125: 2956-2957, 2012.

12. Song C, Koh MJ, Yoon YN, Joung B, Kim SH. IgG4-related sclerosing disease involving the superior vena cava and the atrial septum of the heart. Yonsei Med J 54: 1285-1288, 2013.

13. Yamauchi H, Satoh H, Yamashita T, et al. Immunoglobulin G4 related disease of the heart causing aortic regurgitation and heart block. Ann Thorac Surg 95: e151-e153, 2013.

14. Gutierrez PS, Schultz T, Siqueira SA, de Figueiredo Borges L. Sudden coronary death due to IgG4-related disease. Cardiovasc Pathol 22: 505-507, 2013.

15. Kouzu H, Miki T, Mizuno M, et al. Inflammatory myofibroblastic tumor of the heart. Overlap with IgG4-related disease? Circ J 78: 1006-1008, 2014.

16. Patel NR, Anzalone ML, Buja LM, Elghetany MT. Sudden cardiac death due to coronary artery involvement by IgG4-related disease: a rare, serious complication of a rare disease. Arch Pathol Lab Med 138: 833-836, 2014

17. Besik J, Pirk J, Netuka I, et al. Aortic and mitral valve replacement due to extensive inflammatory immunoglobulin G4-related pseudotumor. Ann Thorac Surg 100: 1439-1441, 2015.

18. Maleszewski JJ, Tazelaar HD, Horcher HM, et al. IgG4-related disease of the aortic valve: a report of two cases and review of the literature. Cardiovasc Pathol 24: 56-59, 2015.

19. Li L, Wang Z, Xu P, Ruan Y, Jiang W, Wu Z. Cardiac mass, aortic intramural hematoma, and IgG4-related disease: a case report. Ann Vasc Surg 35: 208 e205-e208, 2016.

20. Ishida M, Sakaguchi T, Miyagawa S, et al. Right ventricular outflow tract obstruction due to immunoglobulin G4-related disease. Ann Thorac Surg 103: e235-e237, 2017.

21. Yokohama A, Karasawa M, Sakai H, et al. Molecular detection of tumor cells at diagnosis invading the bone marrow and peripheral blood of patients with aggressive or indolent lymphomas. Leuk Res 25: 749-755, 2001.

22. van Dongen JJ, Langerak AW, Brüggemann M, et al. Design and standardization of PCR primers and protocols for detection of clonal immunoglobulin and $\mathrm{T}$-cell receptor gene recombinations in suspect lymphoproliferations: report of the BIOMED-2 Concerted Action BMH4-CT98-3936. Leukemia 17: 2257-2317, 2003.

23. Cheuk W, Yuen HK, Chan AC, et al. Ocular adnexal lymphoma associated with IgG4+ chronic sclerosing dacryoadenitis: a previously undescribed complication of IgG4-related sclerosing disease. Am J Surg Pathol 32: 1159-1167, 2008.

24. Sato $\mathrm{Y}$, Takata $\mathrm{K}$, Ichimura $\mathrm{K}$, et al. IgG4-producing marginal zone B-cell lymphoma. Int J Hematol 88: 428-433, 2008.

25. Kubota T, Moritani S, Yoshino $T$, Nagai H, Terasaki H. Ocular adnexal marginal zone B cell lymphoma infiltrated by IgG4positive plasma cells. J Clin Pathol 63: 1059-1065, 2010.

26. Oyama T, Takizawa J, Nakamura N, Aoki S, Aizawa Y, Abe H. Multifocal mucosa-associated lymphoid tissue lymphoma associated with IgG4-related disease: a case report. Jpn J Ophthalmol 55: 304-306, 2011.

27. Takahashi N, Ghazale AH, Smyrk TC, Mandrekar JN, Chari ST. Possible association between IgG4-associated systemic disease with or without autoimmune pancreatitis and non-Hodgkin lymphoma. Pancreas 38: 523-526, 2009.

28. Uehara T, Ikeda S, Hamano H, et al. A case of Mikulicz's disease complicated by malignant lymphoma: a postmortem histopathological finding. Intern Med 51: 419-423, 2012.

29. Mitsui T, Yokohama A, Koiso H, et al. Development of IgG4related disease 10 years after chemotherapy for diffuse large B cell lymphoma and longstanding bronchial asthma. Int J Hematol 98: 122-128, 2013.

The Internal Medicine is an Open Access journal distributed under the Creative Commons Attribution-NonCommercial-NoDerivatives 4.0 International License. To view the details of this license, please visit (https://creativecommons.org/licenses/ by-nc-nd/4.0/).

(C) 2020 The Japanese Society of Internal Medicine Intern Med 59: 1203-1209, 2020 